\title{
WORKSHOP PEMBIMBINGAN PENELITIAN TINDAKAN KELAS (PTK) DAN KARYA ILMIAH PADA GURU DI SDN 2 DAN SDN 100 KOTA KENDARI
}

\author{
${ }^{1}$ Muhammad Yasin, ${ }^{2}$ Nana Sumarna, ${ }^{3}$ Izlan Sentrio, ${ }^{4}$ La Ode Kaimudin, ${ }^{5}$ Lisnawati \\ 12345 Universitas Halu Oleo \\ Email: muhammad.yasin.unhalu@gmail.com
}

\section{RINGKASAN}

Pengabdian ini bertujuan untuk memberikan bimbingan pemahaman tentang pentingnya PTK dan karya ilmiah inovatif bagi peningkatan kompetensi profesional dan kompetensi pedagogik guru, tindakan perbaikan kinerja guru, serta memberikan bimbingan / pendampingan kepada guru mitra dalam melakukan PTK. Para guru yang bertugas di SD negeri 2 dan SDN 100 Kendari ini memiliki potensi, minat dan motivasi yang cukup tinggi. Target dan luaran pelatihan ini secara kuantitas dari 45 guru yang mengikuti aktivitas PTK dan menulis karya ilmiah $95 \%$ berhasil dengan nilai baik atau dapat disimpulakan bahwa meningkat keyakinan bahwa dengan memiliki kemampuan meneliti dan menulis dijurnal nasional ber ISSN akan berdampak positif pada peningkatan kualitas hasil pendidikan ditingkat SD. Demikian juga hasil karya ilmiah (publikasi ilmiah dan karya inovatif) berdampak langsung pada peningkatan kualitas kerja, berkelanjutan pada perbaikan tugas kedepan, yaitu memperoleh angka kredit bagi guru yang mengusulkan kenaikan pangkat. Pelatihan ini berhasil diikuti oleh 44 orang guru PNS, 1 orang guru non PNS. Dalam evaluasi akhir pelatihan mendapat nilai baik $75 \%$ dan sangat baik $25 \%$. Solusi yang dapat dilakukan untuk mengatasi permasalahan yang dirasakan oleh mitra, maka kegitan ini ditik dari segi kualifikasi pendidikan akademik guru di Kota Kendari $85 \%$ telah memiliki ijazah S1 atau D4, bahkan ada yang sudah S2, dan telah mengikuti pemantapan latihan pengembangan profesi guru, namun karena kegiatan PTK dan karya tulis membutuhkan bimbingan intensif, perlu ada mitra untuk mendiskusikan pengertian konsep, prinsip PTK, model PTK dan langkah membuat laporan hasil PTK yang tepat dengan permasalahan secara riil, factual dan actual terjadi di kelas. Kata kunci: Penelitian Tindakan Kelas; Karya Tulis IImiah

\section{A. Latar Belakang}

Guru adalah pendidik profesional. Hal ini sesuai dengan Undang-Undang RI Nomor 20 Tahun 2003 tentang Sistem Pendidikan Nasional, Undang-undang RI Nomor 14 Tahun 2005 tentang Guru dan Dosen, dan Peraturan Pemerintah RI Nomor 19 Tahun 2005 tentang Standar Nasional Pendidikan. Untuk itu, guru dipersyaratkan memiliki kualifikasi 
akademik minimal Sarjana atau Diploma IV (S1/D-IV) yang relevan dan menguasai kompetensi sebagai agen pembelajaran.

Di era pendidikan yang sangat kompetitif ini, guru sebagai seorang pengajar dituntut memiliki kemampuan yang luas dan memadai dalam hal penguasaan materi bidang studi ke-SD-an, metodologi pembelajaran yang efektif, mampu mengantisipasi perkembangan ipteg dan tuntutan orang tua siswa akan kebutuhannya terhadap pretasi belajar anaknya yang baik, anak-anaknya mendapat pengajaran yang bermutu. Semua hal ini sangat erat kaitannya dengan tugas mengajar. Aneta Lf Tilaar dalam disertasinya (2009: 6) mengemukakan kemampuan sebagai suatu kondisi atau kualitas keefektifan, bakat. Dan keberhasilan/kesuksesan. Kemampuan - kemampuan itu antara lain mencakup (1) terampil menyusun program pembelajaran/ mengorganisasi bahan ajar, (ii) terampil melaksanakan proses pembelajaran/menerapkan strategi pembelajaran, dan (iii) tranpil melaksanakan evaluasi pembelajaran. Yang menjadi pertanyaan sekarang adalah bagaiman ke tiga keterampilan tersebut dikaitkan dengan kemampuan meneliti dan menulis karya ilmiah sebagai kebutuhan untuk nailk pangkat, hasil evaluasi pembelajaran yang belum maksimal dapat dilakukan refleksi dan tindakan perbaikan yang dapat dilakukan oleh seorang guru. Hasil evaluasi yang lemah/kurang efektif mampu dijadikan bahan perenungannya dalam memikirkan langkah-langkah pemecahan masalah, agar hasil belajar siswa optimal. Hal demikian yang dapat dijadikan bahan kajian dalam Penelitian Tindkan Kelas.

Pada tahun (2005) Badan Standar Nasional Pendidikan (BSNP), menandaskan dari sepuluh kompetensi guru Salah satu poin dari sepuluh kemampuan guru tersebut adalah kemampuan menafsirkan hasil penelitian. Namun kenyataannya sampai saat ini kemampuan untuk melakukan PTK kurang dapat diaplikasikan sebagai wahana meningkatkan kinerja guru profesional. Padahal hasil-hasil penelitian ilmiah dan praktis sangat baik untuk dijadikan bahan masukan bagi peningkatan mutu pendidikan ditingkat dasar. Para pejabat penentu kebijakan ditingkat Dinas pendidikan belum menurunkan kebijakan yang mangharuskan guru untuk melakukan Penelitian tindakan kelas (PTK) untuk memperbaiki kinerjanya. Pada tahun 1998, PTK sudah mulai dipakai dikalangan 
LPTK tetapi nanti pada tahun 2005 baru mulai tren, sebab hasil penelitian harus dimanfaatkan sebagai acuan guru dalam merefleksi jalannya proses pembelajaran seperti aktivitas mengajar guru, dan aktivitas belajar siswa. Disinilah esensi dari hasil PTK, karena jika kita amati siklus PTK terdiri dari langkah-langkah perencanaan, tindakan, observasi/evaluasi dan refleksi secara daur ulang, jika didalam tindakan (action) ditemukan ada kelemahan apakah pada cara mengajar guru yang kurang efektif atau pada aktivitas belajar siswa yang mengalami kendala dan atau pada pemilihan perangkat pembelajaran yang tidak sesuai dengan materi pembelajaran, sehingga siswa tidak berubah kemampuannya maka dari itu akan diadakan perencanaan ulang untuk perbaikan hasil belajar siswa sampai betul-betul mendapatkan hasil belajar yang optimal.

Kebijakan umum P3G (Proyek Pengembangan Pendidikan Guru) dijelaskan pula bahwa bukan hanya kemampuan profesional yang diperlukan bagi seorang guru yang sangat diidamkan, melainkan diperlukan juga kemampuan pedagogic (kependidikan), kemampuan pribadi dan kemampuan social (Penyempurnaan tersebut dilakukan karena dari pengmatan praktik sehari-hari terkesan bahwa dalam mengajar, guru cenderung mengutamakan mengajar secara mekanistis, dan agak melupakan tugas mendidik.

Di antara butir dari kompetensi profesional guru tersebut yang langsung terkait dengan kebutuhan para guru untuk promosi kenaikan pangkat dan jabatan mulai dari golongan IIIb ke-atas dibutuhkan kemampuan melakukan penelitian sederhana dalam rangka meningkatkan kualitas profesional guru, khususnya kualitas pembelajaran.

Pada dasarnya ada beragam penelitian yang dapat dilakukan oleh guru. Misalnya penelitian deskriptif, penelitian eksperimen dan penelitian tindakan yang lebih popular disebut penelitian tindakan kelas (PTK). PTK ini bukan hanya sekedar mengajar seperti biasanya, tetapi harus mengandung satu pengertian bahwa tindakan yang dilakukan didasarkan atas upaya meningkatkan hasil belajar, yang lebih baik dari sebelumnya. Ide yang dicobakan dalam PTK harus cermerlang dan guru sangat yakin bahwa hasilnya akan lebih baik dari biasanya.

Kementrian Pendidikan dan Kebudayaan menandaskan bahwa tugas guru adalah melaksanakan penelitian sederhana untuk keperluan pengajaran, antara lain: a) mengkaji 
konsep dasar penelitian ilmiah, b) memahami laporan penelitian sederhana untuk kepentingan pengajaran, c) melaksanakan penelitian sederhana.

Kegiatan penelitian menjadi salah satu kompetensi yang harus dimiliki oleh seorang guru yang profesional. Sejak tahun 2015 karena salah satu guru yang berhasil (efektif) dalam pembelajaran adalah bersifat reflektif dan atau berfikir evaluatif. Guru yang demikian selalu belajar dari pengalaman, dan melakukan intropeksi diri.

Mengacu kepada butir analisis situasi, uraian permasalahan mitra yang mencakup hal-hal berikut ini. Menurut Surya dalam Komara Endang (20012:103) bahwa profesionalisme guru mempunyai makna penting, yaitu: (1) profesionalisme memberikan jaminan perlundungan kepada kesejahtraan masyarakat umum, (2) profesionalisme guru merupakan suatu cara untuk memperbaiki profesi pendidikan yang selama ini dianggap oleh sebagian masyarakat rendah;(3) profesionalisme memberikan kemungkinan perbaikan dan pengembangan diri yang memungkinkan guru dapat memberikan pelayanan sebaik mungkin dan memaksimalkan kompetensinya: Kualitas profesionalisme ditunjukkan oleh 5 sikap, yaitu (1) keinginan untuk selalu menampilkan perilaku yang mendekati standar ideal, (2) meningkatkan dan memelihara citra profesi; (3) keinginan untuk senantiasa mengejar kesempatan pengembangan profesional yang dapat meningkatkan dan memperbaiki kualitas pengetahuan dan keterampilannya, (4) mengejar kualitas dan cita-cita dalam profesi, dan (5) memiliki kebanggaan terhadap profesinya.

Guru SD Negeri 100 dan SDN 2 Kendari pada umumnya merupakan khalayak sasaran yang menjadi fokus pada kegiatan pengabdian kepada masyarakat ini. Kenyataan mengalami keterlambatan naik pangkat atau golongan karena angka kredit dari publikasi ilmiah dan karya inovatif karena jarang didapat atau tidak dilakukan dengan baik, belum trampil melakukan PTK (kegiatan Ilmiah). Mereka bersikap acu taacu atau malas melakukan PTK, para guru SD merasa bahwa banyak waktu yang diperlukan untuk meneliti, belum mantap memiliki metodologi penelitian dan belum tercipta budaya meneliti, serta menulis karya ilimah sehingga tidak termotivasi melakukan. Sebagai khalayak sasaran antara strategis, adalah para guru yang sudah sangat membutuhkan 
adanya karya ilmiah sebagai persyaratan untuk kenaikan jabatan fungsionalnya sehingga penting mangadakan pelatihan pembimbingan PTK dan Karya ilmiah ini.

Bagaimana mewujudkan guru Profesional yang mampu membuat karya ilmiah yaitu melakukan penelitian tindakan kelas dan hasil penelitiannya dapat dipublikasi melalui artikel jurnal ilmiah sehingga hasilnya mendapat angka kredit (point penting) dalam konstruksi pengembangan profesi guru dan untuk kenaikan pangkat selaku pegawai negeri.

\section{B. Metode Pelaksanaan}

Program pengabdian kepada masyarakat ini bertujuan untuk: (1) memberikan bimbingan pemahaman tentang pentingnya tarampil melakukan Penelitian Tindakan Kelas (PTK) bagi guru SD dalam berupaya meningkatkan kompetensi profesional dan kompetensi pedagogic. Diharapkan kepada mitra dapat meningkatkan keterampilan melakukan perbaikan kinerja melalui PTK, (2) mampu memecahkan masalah sosial (bidang pendidikan) yang sering terjadi pada saat proses pembelajaran di kelas, (3) memberikan tindakan perbaikan kinerja yang tepat, dan (4) memberikan bimbingan/pendampingan kepada guru mitra dalam bentuk kegiatan praktek membuat proposal dan membuat laporan hasil PTK dan teknik menulis artikel yang bakal diaplikasikan dalam bentuk karya inovatif dan produktif.

Solusi untuk mengatasi permasalahan yang ada, dapat dilakukan melalui pendekatan pelatihan dan bimbingan teknis dengan menerapkan metode ekspositori, diskusi kelompok dan praktek membuat proposal dan draf artikel. Kegiatan ini menjadi plot percontohan yang akan berguna bagi semua pihak terkait dengan PTK dan karya tulis serta diharapkan berguna sebagai referensi bagi guru-guru yang ingin melalukan kegiatan yang lebih luas dan dalam serta semua pihak yang akan melaksanakan kegiatan sejenis.

Metode yang digunakan dalam kegiatan ini adalah metode ceramah, diskusi dan pemberian tugas menulis proposal PTK dan Langkah penulisan karya ilmiah berupa artikel hasil PTK yang siap dipublikasi dalam jurnal nasional ber-ISSN. 


\section{Hasil dan Pembahasan}

Target dan luaran adalah untuk meningkat kompetensi profesional, dan kapasitas guru dalam kegiatan pendidikan dan pengajaran di sekolah. laporan hasil PTK bakal dapat dipublikasikan pada jurnal nasional ber ISSN. Hasil karya ilmiah (publikasi ilmiah dan karya inovatif) berdampak langsung pada peningkatan kualitas kerja, perbaikan tugas profesional kedepan, mudah memperoleh angka kredit bagi guru yang akan mengusulkan kenaikan pangkat. Materi pembelajaran yang diberikan adalah meliputi teknik perencanaan, langkah tindakan perbaikan pembelajaran, observasi/evaluasi hasil, teknik analisis data, interpretasi hasil, dan refleksi diri sampai dengan teknik membuat laporan hasil PTK dan teknik menulis artikel untuk diterbitkan dalam jurnal hasil penelitian. Pelatihan ini berhasil diikuti oleh 44 orang guru PNS, 1 orang guru non PNS. Peserta 32 orang berasal dari SDN 2 dan 12 orang guru ditugaskan oleh Ka SDN 100 KDI, serta 3 orang mahasiswa, dan 5 orang tim nara sumber dari LPPM UHO memberikan materi penyuluhan secara bergantian terjadwal secara terstruktur.

Semua peserta 45 orang berpartisipasi aktif, mengikuti semua rangkaian kegiatan pelatihan sampai penutupan berakhir. Berdasarkan hasil hanya 1 (satu) orang yang kurang berhasil, sedangkan yang mendapat nilai baik $75 \%$ dan sangat baik 25

\section{Kesimpulan}

Kegiatan ini sangat membantu guru dalam mengembangkan karir dan profesinya dengan trampil menyusun proposal PTK, melaksanakan penelitian, menyusun laporan PTK. Membuat draft artikel yang dirangkum dari laporan hasil penelitian atau Karya ilmiah, kreatif dan inovatif. Secara langsung meningkatkan kualitas mutu pembelajaran dan atau mutu pendidikan dasar dan secara tidak langsung menunjang kredit point kenaikan pangkat bagi guru PNS

Mengingat manfaat yang dapat diperoleh para guru dari kegiatan ini sangat berguna bagi peningkatan kapasitas keilmuan dan keterampilan meneliti dan karya tulis ilmiah, maka kegitan ini dapat dilakukan berkelanjutan disertai dengan melaksanakan penelitian tindakan kelas bagi guru yang segra naik pangkat. Hasil kegiatan ini diharapkan dapat menjadi plot percontohan yang akan berguna bagi semua pihak terkait dengan 
pengembangan diri dalam bidang kegiatan ilmiah serta diharapkan berguna sebagai referensi bagi guru peneliti lainya dan semua mahasiswa yang akan melaksanakan kegiatan sejenis yang lebih berbobot dan spesifik permasalahannya.

\section{E. Ucapan Terima Kasih}

Kami mengucapkan banyak terimakasih kepada Universitas Halu Oleo melalui bidang pengabdian kepada masyarakat karena telah memberikan bantuan dana dalam pelaksanaan kegiatan ini. Kami juga mengucapkan terima kasih tak terhingga kepada Sekolah Darat Negeri 2 Kendari dan Sekolah Dasar Negeri 100 Kendari yang telah memberikan izin kepada kami untuk melakukan workshop melalui bidang pengabdian kepada masyarakat. Ucapan yang sama kami sampaikan pula kepada para mahasiswa yang sudah terlibat aktif di lapangan dalam menyukseskan kegiatan Pengabdian kepada Masyarakat ini.

\section{DAFTAR PUSTAKA}

Arikunto, Suhardjono, Supardi. (2009). Penelitian Tindakan Kelas. Jakarta: PT Bum Aksara.

Anetha LF Tilaar. (2009). Kinerja Guru Dalam Pembelajaran Matematika. Disertasi PPS Universitas Negeri Jakarta.

Depdiknas. 2006 UU No.20 Tahun 2003 Tentang SISDIKNAS, Fokus Media, Jakarta.

Djaali, Puji Mulyono. (2005). Metode Penelitian Sosial, Jakarta PPS UNJ

Endang, K. (2012). Penelitian Tindakan Kelas dan Peningkatan Profesional Guru. Bandung: PT Refika Aditama.

Zulmasri. (2009). Pedoman Singkat Karya Tulis IImiah, Artikel diakses dari www.zulmasri.ordpress.com diakses pada tanggal 10 juni, 2019

Zuhrin. (2017). Konsep Pendekatan Saintifik (5M). https:// zuhrisindonesia.blogspost.com/2017/04/konspep-pendekatasaintifik.html artikel diakses pada tanggal 9 juni 2019. 